\title{
PROSPECTS FOR BUSINESS CLUSTERS IN THE REPUBLIC OF BULGARIA
}

\section{Antoaneta Kirova}

\author{
Economy and Accounting in Transport Department, "Todor Kableshkov" \\ University of Transport, Sofia, Bulgaria
}

CMESTE

JEL Category: F63, 011, Q32

\begin{abstract}
The concept of business clusters dates to the emergence of industrial centers backed by trade during the late Renaissance and the early modern period. The modern economic map abounds with clusters, i.e. concentrated critical masses of geographically co-located companies, but clusters are not unique. They represent typical structures, maintaining the competitive advantages based on local conditions, traditions, and resources, aiming at raising these competitive advantages at a global level. Clusters are increasingly becoming an important feature of modern economies. The positioning of Bulgaria in the field of global technologies imposed and maintained by the leading economies implies an appropriate policy at a state level strongly dependent on innovations. On the other hand, innovations are linked with the potential for development of high-quality education in Bulgaria, based on knowledge, skills, and capacity for absorption and further development of new technologies, but coordination of innovation, education, and training policies with the needs of the labor market is required. From the economic and political point of view, business clusters can boost the economic development at the regional level in Bulgaria, due to the inclusion of the existing elements of the innovation infrastructure. On the other hand, the development and creation of new clusters is an important prerequisite for the establishment of sustainable links between education, training, and business, thus contributing to the implementation of standards for new competencies and professions. The location of vocational schools and relevant universities also predetermines the geographic positioning of clusters.
\end{abstract}

Keywords: Business clusters, two approaches for economic development, new emerging industries, added value

\section{INTRODUCTION}

The concept of business clusters dates to the emergence of industrial centers backed by trade during the late Renaissance and the early modern period. Examples are represented by the London
Financial and Insurance Cluster, United Kingdom, the Wine Cluster in Bordeaux, France, and others. Contemporary examples are the high-tech clusters in the Silicon Valley - a center of 
excellence in the field of $\mathrm{ICT}^{1}$, production centers such as Shenzhen's specialized economic zone in China show the strength and scale of clusters.

The modern economic map abounds with clusters, i.e. concentrated critical masses of geographically co-located companies, but clusters are not unique. They represent typical structures, maintaining the competitive advantages based on local conditions, traditions, and resources, aiming at raising these competitive advantages at a global level. Clusters are increasingly becoming an important feature of modern economies. Their presence is clearly expressed within the global economy, with good positioning of strong cluster structures and the existence of empirical data generated recently confirming the narrow relationship between their economic performance and the level of the national and regional economy (Ketels, 2017).

Clusters are an area of political interest aiding the implementation of economic policy and may be the basis of the conceptual framework for future development. Clusters can improve the effectiveness of the chosen economic policy toolkit and the economic benefits of existing clusters are assessed as multi-layered. Still, the problem of creating and developing new clusters under the conditions of traditional industrial policy is complicated, because clustering requires a favorable business ecosystem.

The European Commission and its associated institutions, including the European Council and the European Parliament, also admit the great importance and value of business clusters, which is confirmed by key policy documents concerning innovation, competitiveness, SME development policy, and cluster policies. At the same time, the Commission contemplates over the major challenge, i.e. the spread of cluster initiatives with little chance of long-term success should be avoided. The European policy itself illustrates certain fragmentation. On one hand, the funding provided for cluster initiatives is often limited and, on the other hand, funding is usually time-bound, meaning connection to the life cycle of

1 „As more high-tech companies were established across San Jose and the Santa Clara Valley, and then north towards the Bay Area's two other major cities, San Francisco, and Oakland, the 'Silicon Valley' has come to have two definitions: a geographic one, referring to Santa Clara County, and another, referring to all hightech businesses in the Bay Area (Silicon Valley, 2018)" implemented project activities. Clusters certainly did not benefit from the permanent institutional framework in the field of professional training and there is no guarantee of an immediate effect on the labor conditions or the style of community life.

Notwithstanding the weaknesses highlighted, many European clusters are becoming more competitive and well organized. They can benefit from close links with research organizations and universities and develop valuable services for members. As cluster activities become more structured in the context of European policy and new research and emerging case studies prove successful cluster initiatives, it is certain that within the present program period 2014-2020 European cluster policy will continue to adapt at the national and regional level, with focus on innovations, science, and technologies.

The priorities in cluster policy in Bulgaria should be based on two main components: first, the growing demand for final industrial products in the global market and second, their potential to respond to demand through competitive products in terms of unit costs or quality (utility). The starting points in the analysis of the degree of readiness for cluster formation are as follows:

- Export orientation;

- Regional specialization and availability of supportive economic activities (according to the diamond competitiveness of Michael Porter);

- The possibilities of creating added value;

- Potential for job creation or increasing labor productivity;

- Innovation potential.

Another point of view on the potential of cluster development, apart from innovation and regional specialization is the opportunity to focus on existing national competences and traditions $\{1\}$, which could be presented by cluster "Bulgarian Yoghurt" (exporting production technology and know-how), cluster "Bulgarian rose oil" (development of the cosmetic and perfumery industry on the basis of effective production of

or even in the USA. The name also became a global synonym for leading high-tech research and enterprises, and thus inspired similarly named locations, as well as parks and technology centers with a comparable structure all around the world. 
Bulgarian rose oil), cluster "Production of electricity from biomass" (for development of technologies and equipment for generating electricity from different biomass). There are good prospects for the establishment of a Textile "Silk" Cluster on a territorial basis, aiming at the restoration of the production of natural silk.

Favorable conditions for the development of clusters are also available in cross-border areas, combining diverse activities in the field of tourism, cultural heritage, environmental protection, organic farming and livestock breeding, education, and culture. The activity of such clusters would enlarge the territorial scope of economic and innovation activities, which in turn leads to improved employment conditions, maximum use of territorial potentials and increased economic activity of backward areas.

\section{ECONOMIC DEVELOPMENT BASED UPON INNOVATION AND CLUSTERING}

There is a three-sector hypothesis in the economy (The Three Economic Sectors, 2017), according to which there are primary, secondary, and tertiary sectors (in some cases the fourth and fifth sectors are added to the 3-sector hypothesis). The basis for their determination is the activity performed. The extraction of raw materials represents the primary economic sector to be processed, namely extraction of minerals, production of agricultural products, logging, hunting, fishing, and extraction of salt. The secondary sector is engaged in the processing of these materials (industrial, metallurgy, woodworking, construction, etc.) The tertiary sector is considered as serving and includes transport, finance, health, culture, education, etc.

Adapted after Michael Porter (1998), in Table 1, the basic differences between the traditional, based upon three sectoral approaches and the new approach based upon clustering are identified.

Despite the differences between them, both approaches support the establishment of clusters, with the first focusing on "traditional, geographic positioning, building competencies, and naturefriendly resources", while the implementation of the second approach requires innovative clusters developing new activities. The present paper is discussing the opportunities of cluster development in the field of the new rising economies.

Table 1. Traditional industrial approach versus cluster-based approach

\begin{tabular}{|c|c|}
\hline Sectoral approach & An approach based on clustering \\
\hline 1 & 2 \\
\hline Groups with similar network positions & $\begin{array}{l}\text { Strategic groups with predominantly } \\
\text { complementary network positions }\end{array}$ \\
\hline Focusing on direct and indirect competitors & $\begin{array}{l}\text { The inclusion of an array of interconnected } \\
\text { industries sharing common technologies, skills, } \\
\text { information, resources, clients, and channels }\end{array}$ \\
\hline Reluctance to cooperate with the competition & $\begin{array}{l}\text { Most participants are not direct competitors but } \\
\text { share common necessities and are subject to } \\
\text { the same constraints }\end{array}$ \\
\hline $\begin{array}{l}\text { The dialogue with government authorities is } \\
\text { often geared to subsidies, seeking protection } \\
\text { and attempts to restrict competition }\end{array}$ & $\begin{array}{l}\text { - A broad platform to improve areas of } \\
\text { common interest that will improve } \\
\text { productivity and increase the level of } \\
\text { competition; } \\
\text { - Forum for a more constructive and effective } \\
\text { dialogue between representatives of } \\
\text { business and authorities }\end{array}$ \\
\hline Searching diversity in existing frameworks & Searching for synergy and new combinations \\
\hline
\end{tabular}


The positioning of Bulgaria in the field of global technologies imposed and maintained by the leading economies implies an appropriate innovation policy at a state level. There is a potential for development of high-quality education in Bulgaria, based on knowledge, skills, and capacity for absorption and further development of new technologies, but coordination of innovation, education, and training policies with the needs of the labor market is required.

Another important factor supporting the development of the innovative and high-tech potential of the Bulgarian business is the provision of its access to additional markets and to sources of project, grant, and commercial financing through the membership of the Republic of Bulgaria in European organizations with high technology activities. There is funding available for research and innovation activities through the Horizon 2020 Program as well as private investment sources provided by leading industrial companies for the transfer of new technologies into practice. There is also an expressed intention towards comprehensive digitization of different types of activities.

The concept of e-government is outlined in the Strategy for e-Government in Bulgaria (SEGA,
2014), adopted in 2002, initiated the processes of creating e-services for citizens and business as well as the establishment of an internal administrative information and communication infrastructure. The main strategic documents that prioritize e-government are the Government Program for European Development of Bulgaria 2009-2013, the Declaration of Ministers in charge of European Union e-Government policies and the Lisbon Strategy adopted in Malmö in 2009.

According to the data of the National Institute of Statistics for 2016, $91.3 \%$ of the enterprises in Bulgaria use the Internet, while $50.7 \%$ of them are in possession of a web page. Both indicators are predominant for large enterprises, with more than 250 people personnel. Over $75 \%$ of the companies use links to public institutions, $46.9 \%$ issue e-invoices (big companies are leading again), but only $6.7 \%$ use cloud services. At the same time, the share of enterprises involved in the system of e-commerce is still small, $8.6 \%$ process orders electronically, while $10.7 \%$ offer delivery of products online.

According to the data of the National Institute of Statistics, published in 2016, the innovative enterprises for 2014 in Bulgaria are as follows:

Table 2. The share of innovative enterprises in the total number of enterprises

\begin{tabular}{|l|c|c|c|}
\hline \multirow{2}{*}{$\begin{array}{c}\text { Economic activities NACE - } \\
\text { 2008) Groups by the size of } \\
\text { enterprises determined by the } \\
\text { number of employees }\end{array}$} & $\begin{array}{c}\mid 3 \\
\text { Innovative } \\
\text { enterprises }\end{array}$ & $\begin{array}{c}\text { Enterprises with } \\
\text { technological } \\
\text { innovation }\end{array}$ & $\begin{array}{c}\text { Enterprises with } \\
\text { non-technological } \\
\text { innovation }\end{array}$ \\
\hline $\mathbf{1}$ & $\mathbf{2}$ & $\mathbf{3}$ & $\mathbf{4}$ \\
\hline Industry & 29.7 & 21.6 & 16.1 \\
\hline Total & 26.1 & 17.1 & 16.3 \\
\hline 10- 49 personnel & 20.6 & 13.1 & 12.5 \\
\hline 50- 249 personnel & 38.8 & 27.7 & 23.9 \\
\hline Over 250 personnel & 78.3 & 46.4 & 57.5 \\
\hline
\end{tabular}

Source: (NSI, 2016)

At the same time, for a similar period, the relative share of enterprises inventing new or offering improved products is barely $5.7 \%$. The share of enterprises with innovative cooperation is $20.6 \%$, with a predominance of the big enterprises.
The graph below shows, first, that the number of innovative enterprises in industry and service sectors is comparable, but process innovation enterprises are less than the technologically innovative ones. 


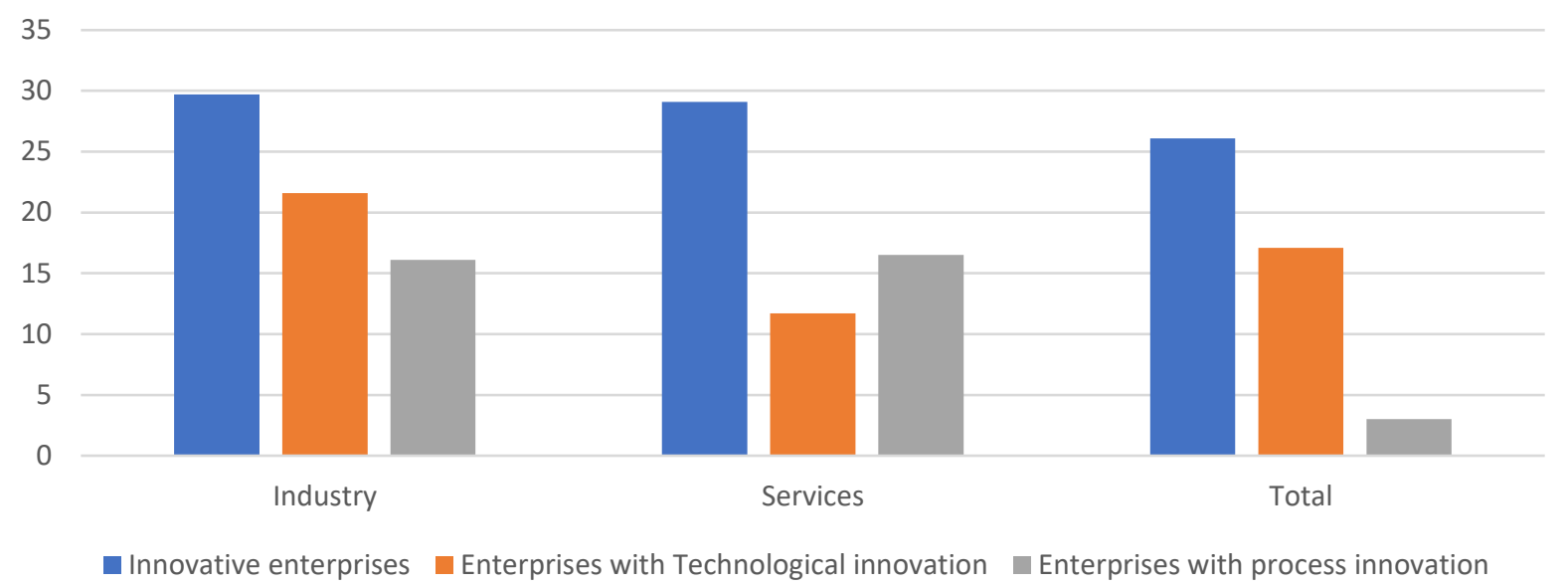

Figure 1. Innovation enterprises in Bulgaria (adapted by the statistical data of NSI)

The data analysis confirms the obvious outcome that big companies in Bulgaria are innovation and technological leaders.

\section{NEW EMERGING INDUSTRIES}

According to the United Nations Education Science and Culture Organization, the cultural and creative industries "combine the creation, production, and commercialization of creative contents that are intangible and of a cultural nature" (Cano, Garzon, \& Poussin, 2000). Copyright usually protects these contents and can take the form of a good or a service. Besides all artistic and cultural production, they include architecture and advertising. According to the United Nations Conference on Trade and Development, the creative industries are at the core of the creative economy and are defined as "cycles of production of goods and services that use creativity and intellectual capital as their main input" (UNCTAD, 2010). They are classified by their role as heritage, art, media, and functional creations. According to the Department of Culture, Media, and Sports of the United Kingdom (DCMS, 2015), the creative industries are those activities based on creativity, individual talent, and skill, and that have the potential to create jobs and wealth through the generation and exploitation of intellectual property.

According to the Strategy for Smart Specialization of the Republic of Bulgaria (ME, 2015), emerging areas have been identified as "Creative Industries" (according to the definition of UNESCO Convention). For the period 2008-2012, the number of enterprises in the creative industries in Bulgaria was increased by $23.5 \%$, compared to
$10.6 \%$ for other enterprises in the economy. Added value also increased by $23.5 \%$, while the growth of enterprises in all other sectors was only $0.7 \%$. The most significant is the difference in employment growth. In the creative industries' enterprises, employment for the same period increased by $13.7 \%$, while the overall rate of employment in other sectors decreased by $9.6 \%$. The creative industries in Bulgaria enhance 21 812 enterprises $(7.1 \%$ of all the enterprises in 2012 , compared to $6.3 \%$ in 2008). The number of employed in the creative sector amounts at 88700 or $5 \%$ of employment in enterprises, compared to the share of $3.9 \%$ in 2008 . The added value of enterprises from creative industries is equal to $1,340,000,000$ Euros or $7.6 \%$ of the overall added value. It is obvious that the influence of creative industries over the economic development of Bulgaria is increasing and their contribution shows a dynamic growth, but still $1-2 \%$ on average less than the influence of similar enterprises in the EU economy. The number of enterprises in the creative industries of Bulgaria for the period 20082012 has increased c $23.5 \%$, opposed to $3.8 \%$ for EU, with employment growth of $13.5 \%$ for Bulgaria to $1.6 \%$ for EU. The added value of those enterprises is $23.5 \%$ against $0.9 \%$ for $\mathrm{EU}$.

The new emerging industries in Bulgaria are presented as follows:

- The sector "Printing and reproduction of recorded media" comprises $1.2 \%$ of the industrial production and creates $2.0 \%$ of the industrial added value in the country. The number of employed people amounts at 9.2 thousand $(1.7 \%$ of the employed in the processing sector), but the level of payment is 
lower than the average for the whole industry (598 BGN monthly). The sector has a substantial exporting potential (for EU countries such as Germany and Greece, and non-EU countries - Turkey, Macedonia, and Ukraine). The sector is primarily oriented towards the internal market, facing serious competition from Internet-based editions. The production consists of printing of newspapers and other publications, bindings, prepress, reproduction of recorded media, etc., from 1 262 companies, with $57.6 \%$ being located on the territory of Sofia-city and Plovdiv districts. The number of business agents is large, the establishment of cartels is not an option, but the companies can participate in crossindustry clusters to encourage the development of emerging industries;

- The sector "Manufacturing of metal products" (without machinery and equipment) comprises $5.1 \%$ of the industrial production and creates $8.5 \%$ of the industrial added value in the country. The number of employed people amounts to 53.6 thousand people $(10.2 \%$ of the employed in the processing sector), with wage levels below the average of the country (577 BGN monthly). Within the sector, there are 4662 companies, mostly big enterprises, geographically concentrated in Southwestern, South Central, South Eastern, and North Central regions. Over $50 \%$ of the companies are situated in Sofia area, Plovdiv, Varna, Stara Zagora and Burgas ("Arsenal" JSC, "Etem Bulgaria" JSC, "Dunarit", JSC, etc.);

- Sector "Manufacturing of computer equipment, electronic and optical products" creates $1.2 \%$ of industrial output and around $2.4 \%$ of the industrial added value, employing 8.2 thousand people $(1.6 \%$ of the industrial employment, with wage levels comparatively high for the country, i.e. 926 LGN monthly). The sector is considered innovative, exportoriented and full of prospects. The predominant part of the companies is big enterprises, $60.5 \%$ of them situated in Sofiacity and Plovdiv. Its share in foreign trade is $3.6 \%$ of the overall industrial export, with leading countries Germany, Romania, Italy, USA, and France. The sector is cluster oriented at sectoral and intersectoral levels.
The professional competence in this field is gradually acquired since 1980 and the South Western region is a leader in specialization;

- Sector "Manufacturing of electrical equipment" creates $4.1 \%$ of the output and $4.3 \%$ of the industrial added value, employing 19.7 thousand people (3.8\% of the industrial employment, with wage levels above the average in the country, i.e. 850 BGN.). The industry is promising and innovative, with clustering potential, if a common vision for its development is formed, including the production of energy-saving facilities. The South Eastern region has the highest degree of specialization. The leading export partners are situated in Germany, France, the Netherlands, Italy, and Greece;

- Sector "Manufacturing of motor vehicles, trailers, and semi-trailers" represents $2.3 \%$ of the industrial output, creates $2.7 \%$ of the added value and is still rising in importance for the Bulgarian economy. The sector employs 12.7 thousand people $(2.4 \%$ of the industrial employment, with wage levels around the average in the country, i.e. 702 BGN). The turnover on the foreign markets amounts at approximately 1.09 billion BGN, with an increase of $19.4 \%$ after 2013 , marking $2.9 \%$ of the industrial export ( $\mathrm{n}$ Germany Turkey, Romania, France, and Russia). The sector is important for the achievement of international competitive advantages, innovative because of the opportunities of production of alternatively propelled vehicles, hence highly appropriate for clustering. Leading in terms of specialization of production are the North Central and Southwestern regions. The output and the export in this sector are experiencing a process of growth and technological advance, the main challenge being the lack of investments (such as investments of FIAT in Serbia, Renault, and Ford in Romania). An investment interest is expressed towards the manufacturing of spare parts for vehicles (a German company Kostal opened a plant near the city of Pazardjik). For the period 2000 2016 the number of employed people is 6 times increased, the value of the exported production in 2016 is 1.38 billion BGN, representing $3 \%$ of the total export. The export of different spare parts and accessories, as 
well as bicycles, are also developing, particularly the last listed, placing Bulgaria among the leading European manufacturers and exporters;

- Sector "Manufacturing of other means of transportation" represents $0.9 \%$ of the industrial output and $0.5 \%$ of the industrial added value, employing 4.7 thousand people ( $0.9 \%$ of the industrial employment, with wage levels around the average, i.e. 738 BGN monthly); leading in specialization is the Northeast region. Leading export countries are Germany, France, USA, Belgium, and Greece. By creating the basis for the development of environmentally sound modes of transport - rail and waterborne - the sector should be stimulated for development and one of the possibilities is the introduction of clusters;

- Sector "Manufacturing of machinery and equipment of general and specific purposes" creates $4.5 \%$ of industrial output and around $6.8 \%$ of industrial added-value, employing 30.4 thousand people $(5.8 \%$ of the employed in industry, with wage levels above the average in Bulgaria, i.e. 849 BGN). Specialization is concentrated in North West, South West and South East regions of the country, while leading countries in exports are: Romania, Germany, Italy, Russia, and France. The sector has a high export profile, despite the presence of intense competition in international markets, still, it is subject to certain regulations ${ }^{2}$.

Based upon the analysis, it can be summarized that the new emerging industries already create around $27 \%$ of the industrial added value, with growing levels of output (15.2\%), and are a representation on the export structure of the country. We consider the encouragement of clustering within these sectors as a starting point for their future development growing their innovation and export potentials, hence increasing their role for the international competitive advantages of the county.

\section{CONCLUSION}

According to the Innovation Strategy for Smart Specialization (SEGA, 2014), business clusters can boost the economic development at the regional level in Bulgaria, due to the inclusion of the existing elements of the innovation infrastructure. On the other hand, the development and creation of new clusters is an important prerequisite for the establishment of sustainable connections between education, training, and business, thus contributing to the implementation of standards for new competencies and professions. The location of vocational schools and relevant universities also predetermines the geographic positioning of clusters.

As part of the implementation of its cluster policy, Bulgaria participates in a platform SEENECO (SEENECO, 2011), with the main goal of promoting the professionalism of cluster managers in CEE by implementing tools developed by the European Excellence Initiative for Cluster Excellence (ECEI, 2012), at a regional level. The project focuses on enhancing the competitiveness and sustainability of clusters, at an organizational level, in partnership with national and regional authorities, as well as on the development of the European portfolio of "distinguished" clusters.

\section{WORKS CITED}

Cano, G. A., Garzon, A., \& Poussin, G. (2000). Culture, Trade, and Globalization - Questions and Answers. UNESCO.

DCMS. (2015, Jan. 13). Creative Industries Economic Estimates January 2015 - Key Findings. Retrieved from Department for Digital, Culture, Media \& Sport:

2 Regulation (EC) № 1232/2011 of the European Parliament and European Council (16.11.2011) amending Regulation (EU) № 428/2009 of the Council on the introduction of Community regime for the control of exports, transfer, brokering and transit of dual-use items and technologies, followed by Order of the Minister of Economy of the Republic of Bulgaria. 
https://www.gov.uk/government/publications/creative-industries-economic-estimates-january2015/creative-industries-economic-estimates-january-2015-key-findings

ECEI. (2012, May 22). The quality label for cluster organizations - criteria, processes, the framework of implementation. Retrieved from European Cluster Excellence Initiative (ECEI): http://www.clusterpolisees3.eu/ClusterpoliSEEPortal/resources/cms/documents/2012.05.22_T he_quality_label_and_indicators_for_cluster_organisations_assessment.pdf

Ketels, C. H. (2017, Jun). Cluster Mapping. Retrieved from Institute For Strategy \& Competitiveness, Harvard Business School: https://www.isc.hbs.edu/competitiveness-economicdevelopment/research-and-applications/Pages/cluster-studies.aspx

ME. (2015). Innovation Strategy for Smart Specialisation in the Republic of Bulgaria 2014-2020. Sofia: Ministry of Economy, Republic of Bulgaria. Retrieved from https://www.mi.government.bg/files/useruploads/files/innovations/ris3_26.10.2015_en.pdf

NSI. (2016, June 30). Innovative enterprises, as a share of all enterprises. Retrieved from the National statistical institute, Republic of Bulgaria: http://www.nsi.bg/en/content/6787/innovativeenterprises-share-all-enterprises

Porter, M. E. (1998). Clusters and the new economics of competition. Harvard Business Review, 76(6), 77-90.

SEENECO. (2011). The Handbook - SEENECO. SEENECO. Retrieved from http://www.emicbg.org/analyses/item/162

SEGA. (2014, Mar.). E-Governance Development Strategy - 2014 - 2020 In the Republic of Bulgaria. Retrieved from Ministry of transport, information technologies, and communications (BG): https://www.mtitc.government.bg/sites/default/files/uploads/pdf/e_governance_strategy.pdf

Silicon Valley. (2018, June 3). Retrieved from Wikipedia: https://en.wikipedia.org/wiki/Silicon_Valley

The Three Economic Sectors. (2017, Oct. 14). Retrieved from Quickonomics: https://quickonomics.com/the-three-economic-sectors/

UNCTAD. (2010). Creative Economy: A Feasible Development Options. UNCTAD. Retrieved from 2010

Received for publication: $\quad 09.01 .2018$

Revision received: $\quad 10.06 .2018$

Accepted for publication: $\quad 15.06 .2018$

\section{How to cite this article?}

Style - APA Sixth Edition:

Kirova, A. (2018, July 15). Prospects for Business Clusters in the Republic of Bulgaria. (Z. Cekerevac, Ed.) MEST Journal, 63-71. doi:10.12709/mest.06.06.02.08

Style - Chicago Sixteenth Edition:

Kirova, Antoaneta. 2018. "Prospects for Business Clusters in the Republic of Bulgaria." Edited by Zoran Cekerevac. MEST Journal 63-71. doi:10.12709/mest.06.06.02.08.

Style - GOST Name Sort:

Kirova Antoaneta Prospects for Business Clusters in the Republic of Bulgaria [Journal] // MEST Journal / ed. Cekerevac Zoran. - Toronto : [s.n.], July 15, 2018. - pp. 63-71. 
Style - Harvard Anglia:

Kirova, A., 2018. Prospects for Business Clusters in the Republic of Bulgaria. MEST Journal, 15 July.pp. 63-71.

Style - ISO 690 Numerical Reference:

Prospects for Business Clusters in the Republic of Bulgaria. Kirova, Antoaneta. [ed.] Zoran Cekerevac. Toronto : s.n., July 15, 2018, MEST Journal, pp. 63-71. 